\title{
Genetic Evaluation of CMS Lines and their Maintainers for Yield and Horticultural Traits in Cabbage (Brassica oleracea var.capitata L.)
}

\author{
Shaina Sharma*, Sanjay Chadha, Nitish Sharma and Paras Singh \\ Department of Vegetable Science and Floriculture, College of Agriculture, CSK Himachal \\ Pradesh Krishi Vishvavidyalaya, Palampur-176062, India \\ *Corresponding author
}

\section{Keywords}

Cabbage, CMS

lines, Yield,

Variability,

Heritability,

Genetic advance

Article Info

Accepted:

20 July 2019

Available Online:

10 August 2019

\section{A B S T R A C T}

The present investigation entitled "Genetic evaluation of CMS lines and their maintainers for yield and horticultural traits in cabbage (Brassica oleracea var.capitataL.)" was carried out at 'Vegetable Research Farm' of the Department of Vegetable Science and Floriculture, CSKHPKV Palampur with the objectives to identify the promising CMS lines and their maintainers and to find out genetic variability. High yielding CMS lines with good combining ability is a pre-requisitefor hybrid development in cabbage. Twenty three genotypes (15 CMS lines+ six maintainer lines + two checks namely KGMR-1 and Varun) were evaluated in Randomized Complete Block Design with three replications during Rabi, 2017-18. Analysis of variance for all the traits viz., plant spread (cm), number of non-wrapper leaves, polar diameter $(\mathrm{cm})$, equatorial diameter $(\mathrm{cm})$, days to harvest, compactness of head $\left(\mathrm{g} / \mathrm{cm}^{3}\right)$, TSS $\left({ }^{0}\right.$ Brix $)$, ascorbic acid content $(\mathrm{mg} / 100 \mathrm{~g})$, gross head weight $(\mathrm{g})$, net head weight $(\mathrm{g})$, marketable heads per plot and marketable head yield per plot $(\mathrm{kg})$ exhibited the presence of sufficient variability in the germplasm as revealed by significant differences for all the characters. Based upon overall performance, genotypes namely II-MCMS (257.63q/ha), GA(P)-105CMS (244.29q/ha), KGAT-II (238.10q/ha), IISCMS $(236.86 \mathrm{q} / \mathrm{ha})$ and III-105CMS $(233.90 \mathrm{q} / \mathrm{ha})$ were found to be the most promising for marketable head yield (q/ha) and various other horticultural traits.High PCV estimates were recorded for marketable head yield per plot and net head weight. High heritability coupled with moderate genetic advance was observed for gross head weight, net head weight, number of non-wrapper leaves, head shape index and TSS.

\section{Introduction}

Cabbage, Brassica oleracea var. capitata L. $(2 \mathrm{n}=2 \mathrm{x}=18)$ member of family Brassicaceae is one of the most important cole-group vegetable crops. It is originated from Brassica oleracea var. oleracea L. (syn. Brassica oleracea var. sylvestris L.) commonly known as wild cabbage through mutation, human selection and adaptation. It is rich source of sulphur containing amino acids, minerals, carotenes, ascorbic acid and anti-carcinogenic properties (Singh et al., 2009).In Himachal Pradesh, it is being cultivated extensively as an off-season vegetable. Hybrids are preferred over the open-pollinated varieties on account 
of yield and quality. In developed countries more than $90 \%$ cabbage growing area is under hybrid varieties, whereas it is only $31 \%$ in India (Kumar et al., 2013). Thus, it is important to identify the high yielding hybrid(s) with better quality and adaptability.

Variability is a pre-requisite in crop improvement. Sufficient genetic variability present in the population can be exploited for developing superior cultivars. Earlier, most of the commercial cultivars of cabbage being grown in our country are of temperate type requiring chilling treatment after heading, for period ranging from 6-8 weeks, for bolting and flowering, which is possible in high hills (Zones III and IV) only, where the cabbage seed crop takes two seasons/year. Besides the temperate cultivars give lower heading (\%) and higher proportion of loose heads during summer in the hills due to the prevalence of relatively higher temperatures. To tide over this problem, tropical genotypes have been developed during the last over few decades. In CSKHPKV also, a number of low chill requiring genotypes of cabbage have been developed for the last over two decades and consequently, good seed crop is possible in about 8-9 months period in the mid hills of Himachal Pradesh. The work on incorporation of CMS in these low chill requiring genotypes started in CSKHPKV Palampur during the last one decade had resulted in development of a number of low chill requiring CMS lines quite comparable with their male fertile counterparts. Therefore, considering the importance of cytoplasmic male sterility in the production of hybrid seed in cabbage, present studies were carried out to evaluate the CMS lines and their maintainers for yield and horticultural traits.

\section{Materials and Methods}

The present investigation was carried out at the Vegetable Research Farm of the
Department of Vegetable Science and Floriculture, CSK Himachal Pradesh Krishi Vishvavidyalaya, Palampur, (H.P.), during Rabi, 2017-18. The experimental farm is situated at $32^{\circ} 6^{\prime}$ North latitude, $76^{\circ} 3^{\prime}$ East longitude at an elevation of $1290.8 \mathrm{~m}$ above mean sea level. Sowing of cabbage seeds in nursery was done on $6^{\text {th }}$ September, 2017 and transplanted in the main field on $4^{\text {th }}$ October, 2017 at CSK Himachal Pradesh Krishi Vishvavidalaya, Palampur (HP). The experimental materials consisted of 15 cytoplasmic male sterile (CMS) lines along with their maintainer lines (six) developed and maintained in the Department of Vegetable Science and Floriculture, CSKHPKV, Palampur along with two checks of cabbage (commercial hybrids -KGMR-1 from public and Varun from private sector). All genotypes were transplanted in Randomized Block Design (RBD) with three replications in plot size of $2.7 \mathrm{~m} \times 1.35 \mathrm{~m}$. The genotypes were spaced at $45 \mathrm{~cm}$ between row to row and $45 \mathrm{~cm}$ between plant to plant. The standard cultural practices to raise the crop were followed as per the recommended package of practices for vegetable crops by CSKHPKV, Palampur. Observations were recorded on five randomly marked plants for characters namely plant spread $(\mathrm{cm})$, number of non-wrapper leaves, polar and equatorial diameters of head $(\mathrm{cm})$, days to harvest, head shape index, compactness of head $\left(\mathrm{g} / \mathrm{cm}^{3}\right)$, total soluble solids i.e.TSS ( ${ }^{0}$ Brix), ascorbic acid content $(\mathrm{mg} / 100 \mathrm{~g})$, gross head weight $(\mathrm{g})$, net head weight $(\mathrm{g})$, marketable heads per plot and marketable head yield per plot $(\mathrm{kg})$. The data were statistically analyzed as per the methods given by Panse and Sukhatme (1984). The phenotypic and genotypic coefficients of variation were estimated as suggested by Burton and DeVane (1953). Heritability in broad sense $\left(\mathrm{h}_{\mathrm{bs}}^{2}\right)$ was calculated as per Burton and De Vane (1953) and Johnson et al., (1955). Expected genetic advance (GA) resulting from the selection of 
5 percent superior individuals was calculated as per Burton and DeVane (1953) and Johnson et al., (1955).

\section{Statistical analysis}

The statistical analysis was carried out for each observed character under study using MS-Excel and OPSTAT (developed by CCS Haryana Agricultural University, Hisar, India).

\section{Results and Discussion}

Analysis of variance for the experimental data revealed that mean squares due to genotypes were significant for all the traits studied (Table 2). GA(P) was found to have the least plant spread $(31.86 \mathrm{~cm})$ among 23 genotypes and was statistically at par with genotypes GA(P)-SCMS, GA(P)-MCMS, Glory-7, Glory-7-SCMS, Glory-I, KGAT-III, KGATII, II-MCMS, I-SCMS, II-105CMS, Glory-ISCMS, Glory-7-MCMS, KGAT-1 including both the checks viz., KGMR-I and Varun. Range for plant spread varied from 31.86 $44.94 \mathrm{~cm}$. These findings are in close conformity with findings of Thakur and Vidyasagar (2016) who reported a wide range of plant spread in their germplasm. The number of non-wrapper leaves varied from 10.67-14.33. GA(P)-SCMS (10.67) was found to have the minimum number of leaves and it was statistically at par with six other genotypes namely, II-SCMS, GA(P), KGATIII and the check KGMR-I, KGAT-II and III105CMS. Genotype GA(P)-SCMS was found superior to check Varun. Thakur and Thakur (2002a), Atter (2004), Singh et al., (2011) and Singh et al., (2013) also reported variation in number of non-wrapper leaves. Polar diameter varied from 9.85 to $11.94 \mathrm{~cm}$. Genotype GA(P)-105CMS $(11.94 \mathrm{~cm})$ was found to have the maximum polar diameter and was statistically at par with eight other genotypes namely, GA(P), III-105CMS,
GA(P)-SCMS, I-SCMS, I-MCMS, II-MCMS, I-105CMS, KGAT-III and KGAT-II, but superior to both the checks KGMR-1 and Varun. Genotypes viz., GA(P) and III$105 \mathrm{CMS}$ were also found to be significantly superior to check KGMR-1.Table 3 showed a range of 9.34 to $13.53 \mathrm{~cm}$ for equatorial diameter. III-105CMS was found to have the maximum equatorial diameter $(13.53 \mathrm{~cm})$ and it was statistically at par with II-SCMS, IIMCMS, KGAT-II, GA(P)-105CMS. All these above genotypes were found to be superior to both the checks KGMR-I and Varun. Apart from these five genotypes, three genotypes over Varun and nine over KGMR-I were also found to be significantly superior. The significant differences for polar and equatorial diameters were observed by Singh et al., (2011). I-105CMS was the earliest to produce marketable heads (117.20 days) and 13 genotypes were statistically at par viz., KGAT-II, GA(P), II-MCMS, Glory-I, GloryI-SCMS, Glory-I-MCMS, II-SCMS, KGAT-I, GA(P)-SCMS, II-105CMS, Glory-7-MCMS, I-MCMS and I-SCMS. All the genotypes were found superior to both the checks viz., KGMR-1 (144.66 days) and Varun (140.97 days).Various earlier workers viz., Thakur and Thakur (2002a), Atter (2004), Atter et al., (2009), Meena et al., (2009), Singh et al., (2011), Singh et al., (2013) and Kibar et al., (2014) found variability in days to maturity. The head shape index varied from 0.78 to 1.11. KGMR-I (1.11) was found with maximum head shape index and statistically at par with genotypes Varun, GA(P), Glory-7. Other than the above genotypes, GA(P)SCMS, GA(P)-MCMS, I-105CMS and KGAT-III also showed pointed heads. Genotype II-SCMS showed flat type head. Rest of the genotypes showed round heads. Earlier researchers Thakur and Thakur (2002a) and Atter (2004) also depicted significant differences for head shape index. The compactness of head varied from 32.00$43.94 \mathrm{~g} / \mathrm{cm}^{3}$. The check variety KGMR-1 
$\left(43.94 \mathrm{~g} / \mathrm{cm}^{3}\right)$ had the maximum compactness value and statistically at par with Varun, Glory-7-SCMS, III-MCMS, I-105CMS, Glory I-SCMS, Glory-I, KGAT-I and IISCMS. These results are similar with the findings of Thakur and Thakur (2002a) and Atter (2004). The maximum TSS was recorded in KGAT-II $\left(6.77^{\circ}\right.$ Brix $)$ and was statistically at par with five other genotypes KGAT-III, II-MCMS, I-105CMS and II105CMS and Glory-7-MCMS. All genotypes except Glory-7-SCMS, Glory I-SCMS, GA(P), KGAT-I and Glory-I were found significantly superior to the check KGMR-I, while only one genotype KGAT-II was found superior to Varun. The range for ascorbic acid content varied from 8.67-15.0 mg/100g. The highest ascorbic acid content was recorded in II-MCMS and was statistically at par with 10 other genotypes including checks viz., I105CMS, Glory-I-MCMS, KGAT-II, II105CMS, GA(P)-105 CMS, KGMR-I, III105CMS, GA(P)-MCMS, GA(P)-SCMS and Varun. Singh et al., (2006) in study of antioxidant phyto-chemicals in cabbage reported that ascorbic acid content ranged from 5.66 to $23.50 \mathrm{mg} / 100 \mathrm{~g}$ fresh weight.GA(P)-105CMS was found to have the maximum gross head weight and was statistically at par with genotype III-105CMS. Both the above genotypes including IIMCMS, Glory I-SCMS, II-SCMS, I105CMS, KGAT-II, III-MCMS and I-MCMS were found superior to both the checks KGMR-I and Varun and genotypes viz., Glory-I, GA(P)-SCMS, KGAT-III, Glory-7MCMS, GA(P), Glory-1-MCMS, II-105CMS, KGMR-1 and GA(P)-MCMS over Varun only. Range of gross head weight varied from 684.23-992.50g. Significant differences for gross head weight were observed by Sharma (2001), Thakur and Thakur (2002a), Atter (2004), Atter et al., (2009), Meena et al., (2009), Singh et al., (2011) and Thakur and Vidyasagar (2016). III-105CMS exhibited the maximum net head weight $(729.33 \mathrm{~g})$ and was statistically at par with genotypes namely, IISCMS and GA(P)-105CMS. All the above genotypes including II-MCMS and KGAT-II were found to be statistically superior to both the checks Varun and KGMR-I and GA(P)SCMS, III-MCMS and Glory-I-SCMS over KGMR-1 only. Thakur and Thakur (2002a), Atter (2004), Atter et al., (2009), Meena et al., (2009), Richardson (2013) and Thakur and Vidyasagar (2016) revealed significant differences for net head weight. GA(P) had the maximum number of marketable heads per plot (17.67) and was statistically at par with genotypes I-105CMS, II-MCMS, GloryI-SCMS, Glory-I, Glory-7-MCMS, KGAT-II, GA(P)-SCMS, Glory-I-MCMS, I-SCMS, II105CMS, III-MCMS, Glory-7 and KGAT-I, GA(P)-105CMS, Glory-7-SCMS and IMCMS. Six genotypes viz., GA(P), I105CMS, II-MCMS, Glory-I-SCMS, Glory-I and Glory-7-MCMS were also found to be superior to both the checks viz., KGMR-1and Varun. The range of marketable head yield varied from $5.63-10.42 \mathrm{~kg}$ (Table 3). IIMCMS (10.42kg) showed the highest yield among all the genotypes and was found statistically at par with ten other genotypes viz., GA(P)-105CMS, KGAT-II, II-SCMS, III-105CMS, Glory-I-SCMS, I-105CMS, GA(P)-SCMS, GA(P), Glory-I and IIIMCMS. Of all these above 11 genotypes, all genotypes over KGMR-I and six top over Varun were also found to be superior. Atter (2004), Adeniji et al., (2010), Kibar et al., (2014) and Thakur and Vidyasagar (2016) have also reported significant differences in marketable head yield.

\section{Parameters of variability}

\section{Coefficient of variation}

The phenotypic coefficient of variation ranged from 7.31 to $21.25 \%$. High phenotypic coefficient of variation existed for marketable head yield per plot and net head weight. 
Table.1 List of CMS and maintainer lines

\begin{tabular}{|c|l|l|}
\hline Sr. No. & Lines & Source \\
\hline $\mathbf{1}$ & I-MCMS & CSKHPKV, Palampur \\
\hline $\mathbf{2}$ & I-105CMS & -do- \\
\hline $\mathbf{3}$ & I-SCMS & -do- \\
\hline $\mathbf{4}$ & KGAT-1 & -do- \\
\hline $\mathbf{5}$ & II-MCMS & -do- \\
\hline $\mathbf{6}$ & II-105CMS & -do- \\
\hline $\mathbf{7}$ & II-SCMS & -do- \\
\hline $\mathbf{8}$ & KGAT-II & -do- \\
\hline $\mathbf{9}$ & III-MCMS & -do- \\
\hline $\mathbf{1 0}$ & III-105CMS & -do- \\
\hline $\mathbf{1 1}$ & KGAT-III & -do- \\
\hline $\mathbf{1 2}$ & GA(P)-MCMS & -do- \\
\hline $\mathbf{1 3}$ & GA(P)-105CMS & -do- \\
\hline $\mathbf{1 4}$ & GA(P)-SCMS & -do- \\
\hline $\mathbf{1 5}$ & GA(P) & -do- \\
\hline $\mathbf{1 6}$ & Glory I-MCMS & -do- \\
\hline $\mathbf{1 7}$ & Glory I-SCMS & -do- \\
\hline $\mathbf{1 8}$ & Glory-I & -do- \\
\hline $\mathbf{1 9}$ & Glory-7-MCMS & -do- \\
\hline $\mathbf{2 0}$ & Glory-7-SCMS & -do- \\
\hline $\mathbf{2 1}$ & Glory-7 & -do- \\
\hline $\mathbf{2 2}$ & KGMR-1 (Check-1) & IARI Regional Station, Katrain \\
\hline $\mathbf{2 3}$ & Varun (Check-2) & Private sector \\
\hline & & \\
\hline
\end{tabular}


Table.2 Analysis of variance for randomized block design

\begin{tabular}{|c|c|c|c|c|}
\hline Sr. No. & $\begin{array}{l}\text { Sources of variation } \rightarrow \\
\text { Traits df } \rightarrow\end{array}$ & $\begin{array}{l}\text { Replications } \\
2\end{array}$ & $\begin{array}{l}\text { Genotypes } \\
22\end{array}$ & $\begin{array}{l}\text { Error } \\
44\end{array}$ \\
\hline 1 & Plant spread $(\mathrm{cm})$ & 75.189 & $33.347 *$ & 12.855 \\
\hline 2 & No. of non-wrapper leaves & 1.638 & $3.653^{*}$ & 0.631 \\
\hline 3 & Polar diameter $(\mathrm{cm})$ & 0.629 & $0.944 *$ & 0.460 \\
\hline 4 & Equatorial diameter $(\mathrm{cm})$ & 0.535 & $3.609 *$ & 0.788 \\
\hline 5 & Days to harvest & 66.383 & $162.767 *$ & 50.531 \\
\hline 6 & Head shape index & 0.002 & $0.022 *$ & 0.003 \\
\hline 7 & Compactness of head $\left(\mathrm{g} / \mathrm{cm}^{3}\right)$ & 10.190 & $25.550 *$ & 13.605 \\
\hline 8 & TSS $\left({ }^{0}\right.$ Brix $)$ & 0.275 & $1.744^{*}$ & 0.223 \\
\hline 9 & Ascorbic acid content $(\mathrm{mg} / 100 \mathrm{~g})$ & 2.275 & $8.877^{*}$ & 2.700 \\
\hline 10 & Gross head weight (g) & 5003.252 & $22127.083 *$ & 1995.454 \\
\hline 11 & Net head weight (g) & 3927.838 & $23738.076^{*}$ & 3993.050 \\
\hline 12 & Marketable heads per plot & 2.623 & $3.863^{*}$ & 1.653 \\
\hline 13 & Marketable head yield per plot $(\mathrm{kg})$ & 3.205 & $5.591 *$ & 1.541 \\
\hline
\end{tabular}

* Significant at $5 \%$ level of significance 
Table.3Mean performance of cabbage genotypes forplant spread $(\mathrm{cm})$, number of non -wrapper leaves, polar diameter of head $(\mathrm{cm})$, equatorial diameter of head $(\mathrm{cm})$, days to harvest, head shape index, compactness of head $\left(\mathrm{g} / \mathrm{cm}^{3}\right)$, TSS $\left({ }^{0} \mathrm{Brix}\right)$, ascorbic acid content $(\mathrm{mg} / 100 \mathrm{~g})$, gross head weight $(\mathrm{g})$, net head weight $(\mathrm{g})$, marketable heads per plot, marketable head yield per plot $(\mathrm{kg})$ and marketable head yield ( $\mathrm{q} / \mathrm{ha}$ )

\begin{tabular}{|c|c|c|c|c|c|c|c|c|c|c|c|c|c|c|}
\hline Genotypes & $\begin{array}{l}\text { Plant } \\
\text { spread } \\
\text { (cm) }\end{array}$ & $\begin{array}{c}\text { Number } \\
\text { of non - } \\
\text { wrapper } \\
\text { leaves }\end{array}$ & $\begin{array}{c}\text { Polar } \\
\text { diameter } \\
\text { of head } \\
(\mathbf{c m})\end{array}$ & $\begin{array}{l}\text { Equatorial } \\
\text { diameter } \\
\text { of head } \\
(\mathrm{cm})\end{array}$ & $\begin{array}{l}\text { Days to } \\
\text { harvest }\end{array}$ & $\begin{array}{l}\text { Head } \\
\text { shape } \\
\text { index }\end{array}$ & $\begin{array}{c}\text { Compact } \\
\text { ness of } \\
\text { head } \\
\left(\mathrm{g} / \mathrm{cm}^{3}\right)\end{array}$ & $\begin{array}{c}\text { TSS } \\
\left({ }^{0} \text { Brix }\right)\end{array}$ & $\begin{array}{l}\text { Ascorbic } \\
\text { acid } \\
\text { content } \\
(\mathbf{m g} / \mathbf{1 0 0 g})\end{array}$ & $\begin{array}{c}\text { Gross } \\
\text { head } \\
\text { Weight } \\
\text { (g) }\end{array}$ & $\begin{array}{c}\text { Net } \\
\text { head } \\
\text { weight } \\
\text { (g) }\end{array}$ & $\begin{array}{c}\text { Marke } \\
\text { table } \\
\text { heads } \\
\text { per } \\
\text { plot }\end{array}$ & $\begin{array}{l}\text { Marketab } \\
\text { le head } \\
\text { yield per } \\
\text { plot (kg) }\end{array}$ & $\begin{array}{c}\text { Marke } \\
\text { table } \\
\text { head } \\
\text { yield } \\
\text { (q/ha) }\end{array}$ \\
\hline I-MCMS & 41.83 & 14.33 & 11.03 & 11.08 & 128.04 & 1.00 & 34.02 & 5.93 & 11.00 & 846.99 & 455.32 & 15.67 & 7.09 & 175.30 \\
\hline I-105CMS & 42.24 & 13.00 & 11.00 & 10.78 & 117.20 & 1.02 & 40.03 & 6.27 & 14.67 & 893.33 & 514.17 & 17.33 & 8.90 & 220.05 \\
\hline I-SCMS & 36.92 & 12.67 & 11.10 & 11.65 & 128.33 & 0.96 & 32.00 & 5.33 & 9.67 & 731.67 & 471.67 & 16.00 & 7.59 & 187.66 \\
\hline KGAT-1 & 37.54 & 13.00 & 10.33 & 10.29 & 126.60 & 1.00 & 38.52 & 4.53 & 10.67 & 732.19 & 420.00 & 15.67 & 6.55 & 161.95 \\
\hline II-MCMS & 36.32 & 12.67 & 11.02 & 12.72 & 121.07 & 0.87 & 36.10 & 6.33 & 15.00 & 913.73 & 602.16 & 17.33 & 10.42 & 257.63 \\
\hline II-105CMS & 36.98 & 13.00 & 9.85 & 11.35 & 127.58 & 0.87 & 37.74 & 6.13 & 13.33 & 770.28 & 451.39 & 16.00 & 7.35 & 181.73 \\
\hline II-SCMS & 43.40 & 11.00 & 10.52 & 13.44 & 124.45 & 0.78 & 38.32 & 5.37 & 11.67 & 898.61 & 654.81 & 14.67 & 9.58 & 236.86 \\
\hline KGAT-II & 36.21 & 11.33 & 10.86 & 12.29 & 117.47 & 0.88 & 37.26 & 6.77 & 14.00 & 892.00 & 575.00 & 16.67 & 9.63 & 238.10 \\
\hline III-MCMS & 39.01 & 12.00 & 10.80 & 11.22 & 129.50 & 0.96 & 40.05 & 5.50 & 10.67 & 872.50 & 532.50 & 16.00 & 8.53 & 210.91 \\
\hline III-105CMS & 44.94 & 11.33 & 11.80 & 13.53 & 129.08 & 0.87 & 35.95 & 5.87 & 12.67 & 987.67 & 729.33 & 13.00 & 9.46 & 233.90 \\
\hline KGAT-III & 36.02 & 11.00 & 10.92 & 10.72 & 130.59 & 1.03 & 33.73 & 6.43 & 11.00 & 805.83 & 431.25 & 14.67 & 6.35 & 157.00 \\
\hline GA(P)-MCMS & 35.12 & 12.33 & 10.60 & 10.51 & 134.84 & 1.01 & 37.10 & 5.40 & 12.33 & 758.96 & 435.89 & 15.00 & 6.60 & 163.19 \\
\hline GA(P)-105CMS & 41.13 & 12.00 & 11.94 & 12.21 & 130.22 & 0.98 & 36.01 & 5.37 & 13.00 & 992.50 & 630.83 & 15.67 & 9.88 & 244.29 \\
\hline GA(P)-SCMS & 34.46 & 10.67 & 11.43 & 11.34 & 127.28 & 1.01 & 36.78 & 5.20 & 12.33 & 825.67 & 543.67 & 16.33 & 8.79 & 217.33 \\
\hline $\mathbf{G A}(\mathbf{P})$ & 31.86 & 11.00 & 11.81 & 10.94 & 120.59 & 1.08 & 33.55 & 4.47 & 12.00 & 799.17 & 494.37 & 17.67 & 8.76 & 216.59 \\
\hline Glory I-MCMS & 38.03 & 13.17 & 10.73 & 10.92 & 124.24 & 0.98 & 35.05 & 5.40 & 14.67 & 785.00 & 443.33 & 16.33 & 7.25 & 179.25 \\
\hline Glory I-SCMS & 37.29 & 14.00 & 10.35 & 11.76 & 122.47 & 0.88 & 39.24 & 4.30 & 11.33 & 910.83 & 530.00 & 17.33 & 9.22 & 227.96 \\
\hline Glory-I & 35.68 & 14.00 & 10.40 & 11.34 & 121.64 & 0.92 & 38.61 & 4.67 & 8.67 & 830.83 & 495.83 & 17.33 & 8.66 & 214.12 \\
\hline Glory-7-MCMS & 37.36 & 12.33 & 10.15 & 11.81 & 127.60 & 0.86 & 33.71 & 6.13 & 10.00 & 800.83 & 446.67 & 17.33 & 7.71 & 190.63 \\
\hline Glory-7-SCMS & 35.40 & 12.33 & 10.22 & 10.27 & 132.90 & 1.00 & 41.15 & 4.27 & 10.33 & 747.19 & 442.20 & 15.67 & 6.92 & 171.10 \\
\hline Glory-7 & 35.16 & 14.00 & 10.16 & 9.52 & 143.25 & 1.07 & 36.86 & 5.30 & 10.00 & 690.00 & 351.53 & 16.00 & 5.63 & 139.20 \\
\hline KGMR-1 & 31.88 & 11.00 & 10.34 & 9.34 & 144.66 & 1.11 & 43.94 & 4.03 & 13.00 & 768.24 & 417.86 & 15.00 & 6.20 & 153.30 \\
\hline Varun & 37.24 & 12.01 & 10.80 & 9.94 & 140.97 & 1.09 & 41.32 & 5.67 & 12.33 & 684.23 & 459.05 & 15.00 & 6.90 & 170.60 \\
\hline $\operatorname{SE}(d) \pm$ & 2.93 & 0.65 & 0.55 & 0.72 & 5.80 & 0.04 & 3.012 & 0.39 & 1.34 & 36.47 & 51.59 & 1.05 & 1.01 & \\
\hline CD (5\%) & 5.88 & 1.30 & 1.11 & 1.45 & 11.67 & 0.08 & 6.05 & 0.77 & 2.69 & 73.31 & 103.71 & 2.11 & 2.04 & \\
\hline CV (\%) & 9.57 & 6.43 & 6.28 & 7.89 & 5.54 & 5.57 & 9.90 & 8.72 & 13.77 & 5.425 & 12.61 & 8.04 & 15.51 & \\
\hline Grand Mean & 37.48 & 12.36 & 10.79 & 11.26 & 128.29 & 0.97 & 37.26 & 5.42 & 11.93 & 823.40 & 501.25 & 15.99 & 8.00 & \\
\hline Range & $\begin{array}{l}31.86- \\
44.94\end{array}$ & $\begin{array}{c}10.67- \\
14.33\end{array}$ & $\begin{array}{l}9.85- \\
11.94\end{array}$ & $9.34-13.53$ & $\begin{array}{c}117.20- \\
144.66\end{array}$ & $\begin{array}{c}0.78- \\
1.11\end{array}$ & $\begin{array}{c}32.00- \\
43.94\end{array}$ & $\begin{array}{c}4.03- \\
6.77\end{array}$ & $8.67-15.00$ & $\begin{array}{l}684.23- \\
992.50\end{array}$ & $\begin{array}{c}351.53- \\
729.33\end{array}$ & $\begin{array}{c}13.00- \\
17.67\end{array}$ & $\begin{array}{l}5.63- \\
10.42\end{array}$ & \\
\hline
\end{tabular}


Table.4 Estimates of PCV, GCV, heritability and genetic advance for marketable yield and other traits in cabbage

\begin{tabular}{|c|c|c|c|c|c|}
\hline $\begin{array}{l}\text { Sr. } \\
\text { No. }\end{array}$ & Traits & $\begin{array}{c}\text { PCV } \\
(\%)\end{array}$ & $\begin{array}{c}\text { GCV } \\
(\%)\end{array}$ & $\begin{array}{l}\mathbf{h}_{\text {bs }}^{2} \\
(\%)\end{array}$ & $\begin{array}{c}\text { GA as percentage } \\
\text { of mean }\end{array}$ \\
\hline 1 & Plant spread(cm) & $11.84(\mathrm{M})$ & $6.97(\mathrm{~L})$ & $34.70(\mathrm{M})$ & $8.46(\mathrm{~L})$ \\
\hline 2 & No of non-wrapper leaves & $11.92(\mathrm{M})$ & $6.97(\mathrm{~L})$ & $34.21(\mathrm{M})$ & $8.40(\mathrm{~L})$ \\
\hline 3 & Polar diameter $(\mathrm{cm})$ & $7.31(\mathrm{~L})$ & $3.73(\mathrm{~L})$ & $26.01(\mathrm{~L})$ & $3.91(\mathrm{~L})$ \\
\hline 4 & Equatorial diameter(cm) & $11.68(\mathrm{M})$ & $8.61(\mathrm{~L})$ & $54.39(\mathrm{M})$ & $13.09(\mathrm{M})$ \\
\hline 5 & Days to harvest & 7.31(L) & $4.77(\mathrm{~L})$ & $42.54(\mathrm{M})$ & $6.41(\mathrm{~L})$ \\
\hline 6 & Head shape index & $9.98(\mathrm{~L})$ & $8.26(\mathrm{~L})$ & $68.46(\mathrm{H})$ & $14.08(\mathrm{M})$ \\
\hline 7 & Compactness of head $\left(\mathrm{g} / \mathrm{cm}^{3}\right)$ & $11.25(\mathrm{M})$ & $5.35(\mathrm{~L})$ & $22.64(\mathrm{~L})$ & $5.25(\mathrm{~L})$ \\
\hline 8 & $\operatorname{TSS}\left({ }^{0}\right.$ Brix $)$ & $15.76(\mathrm{M})$ & $13.13(\mathrm{M})$ & $69.42(\mathrm{H})$ & $22.54(\mathrm{M})$ \\
\hline 9 & Ascorbic acid content (mg/100g) & $18.29(\mathrm{M})$ & $12.03(\mathrm{M})$ & $43.27(\mathrm{M})$ & $16.30(\mathrm{M})$ \\
\hline 10 & Gross head weight (g) & $11.33(\mathrm{M})$ & $9.95(\mathrm{~L})$ & $77.08(\mathrm{H})$ & $17.99(\mathrm{M})$ \\
\hline 11 & Net head weight $(g)$ & $20.51(\mathrm{H})$ & $16.18(\mathrm{M})$ & $62.24(\mathrm{H})$ & $26.30(\mathrm{M})$ \\
\hline 12 & Marketable heads per plot & $9.67(\mathrm{~L})$ & $5.37(\mathrm{~L})$ & $30.82(\mathrm{M})$ & $6.14(\mathrm{~L})$ \\
\hline 13 & Marketable head yield per plot (kg) & $21.25(\mathrm{H})$ & $14.52(\mathrm{M})$ & $46.69(\mathrm{M})$ & $20.44(\mathrm{M})$ \\
\hline
\end{tabular}

PCV = Phenotypic coefficient of variation $\{$ Low $(\mathrm{L}):<10 \%$, Moderate (M): 10-20\%, High (H): $>20 \%\}$, GCV = Genotypic coefficient of variation $\{$ Low $(\mathrm{L}):<10 \%$, Moderate (M): 10-20\%, High $(\mathrm{H}):>20 \%\}, \mathrm{h}_{\mathrm{bs}}^{2}=$ Heritability (broad sense) $\{$ Low $(\mathrm{L}):<30 \%$, Moderate $(\mathrm{M}): 30-60 \%$, High $(\mathrm{H}):>60 \%\}, \mathrm{GA}=\mathrm{Genetic}$ advance $\{$ Low (L): $<10 \%$, Moderate (M): 10-30\%, High (H): $>30 \%\}$ 
These high estimates indicated that there is substantial variability ensuring ample scope for improvement of this trait through selection. Moderate PCV was exhibited for ascorbic acid content, TSS, plant spread, equatorial diameter, gross head weight, compactness of headand number of nonwrapper leaves. However, it was found low for head shape index, marketable heads per plot, days to harvest and polar diameter. These results are in consonance with the earlier findings of various researchers for head yield per plot (Thakur and Thakur 2002a,Atter 2004,Atter et al., 2009, Meena et al., 2009, Thakur and Vidyasagar 2016), net head weight (Atter et al., 2009, Meena et al., 2009, Thakur and Vidyasagar 2016), gross head weight, compactness of head, number of non-wrapper leaves (Atter 2004), days to maturity and harvesting index (Thakur and Thakur 2002a, Atter 2004,Atter et al., 2009, Meena et al., 2009). In contrary, (Atter et al., 2009, Meena et al., 2009, Thakur and Vidyasagar 2016, Kaur et al., 2018) reported high PCV for gross head weight.

PCV alone does not reveal the relative amount of variation, hence different aspects of genetic parameters were worked out. In the experimental material, the range of genotypic coefficient of variation varied from 3.73$16.18 \%$. None of the character could show high estimates of GCV, however, moderate GCV was recorded for net head weight, marketable head yield per plot, TSSand ascorbic acid content. Low estimates of GCV were recorded for gross head weight, equatorial diameter, head shape index, number of non-wrapper leaves, plant spread, marketable heads per plot, compactness of head, days to harvest and polar diameter. These results are in agreement with various earlier workers for polar diameter and days to harvest (Meena et al., 2009,Atter 2004, Thakur and Thakur 2002a). In contrary, high GCV were recorded for head compactness
(Thakur and Thakur 2002a), marketable yield (Thakur and Thakur 2002a, Atter 2004, Atter et al., 2009, Meena et al., 2009, Thakur and Vidyasagar 2016), net head weight (Atter 2004, Atter et al., 2009, Meena et al., 2009, Thakur and Vidyasagar 2016), gross head weight (Atter et al., 2009, Meena et al., 2009, Thakur and Vidyasagar 2016).

\section{Heritability and Genetic advance}

\section{Heritability}

High to moderate heritability estimates were obtained for most of the characters. Heritability in broad sense $\left(\mathrm{h}^{2}\right.$ bs $)$ ranged from 22.64-77.08\%. High heritability estimates were obtained for gross head weight, TSS, head shape index and net head weight. Equatorial diameter, marketable head yield per plot, ascorbic acid content, days to harvest, plant spread, number of non-wrapper leaves and marketable heads per plot exhibited moderate estimates of heritability. Rest of the characters viz., polar diameterand compactness of head showed low estimates of heritability. Earlier researchers have also found similar results for net head weight (Thakur and Vidyasagar 2016, Kaur et al., 2018), number of non-wrapper leaves (Soni et al., 2013), head shape (Atter 2004), gross head weight (Atter 2004, Sharma 2010, Thakur and Vidyasagar 2016), TSS (Kaur et al., 2018), Ascorbic acid (Kaur et al., 2018) and compactness of head (Thakur and Vidyasagar 2016, Kaur et al., 2018). In contrary, Meena et al., (2009) reported low heritability for gross head weight.

\section{Genetic advance}

In the present study, none of the character could show high estimates of genetic advance, however, the estimates of genetic advance were moderate for net head weight, TSS, marketable head yield per plot, gross head 
weight, ascorbic acid content, head shape index and equatorial diameter. Low estimates of genetic advance were observed for plant spread, number of non-wrapper leaves, days to harvest, marketable heads per plot, compactness of head and polar diameter. The present findings are in confirmation with findings of Atter (2004) for marketable yield and head shape index, and with Meena et al., (2009) for days to maturity and polardiameter. In contrary, Thakur and Thakur (2002a) and Thakur and Vidyasagar (2016) reported high genetic advance for gross weight and total yield per plot. High genetic advance for yield per plot and net head weight were reported by Meena et al., (2009) and Thakur and Vidyasagar (2016), respectively.

\section{References}

Adeniji OT, Swai I, Oluoch MO, Tanyongana $\mathrm{R}$ and Aloyce A. 2010. Evaluation of head yield and participatory selection of horticultural characters in cabbage (Brassica oleraceaevar. capitata L.). Journal of Plant Breeding and Crop Science 2(8): 243-250.

Atter RS, Sharma KC and Sundouri AS. 2009. Genetic variability, heritability and genetic advance studies in cabbage. Indian Society of Plant Genetic Resources 22: 62-65.

Atter RS. 2004. Study on genetic variability for head yield and component traits in cabbage (Brassica oleracea var. capitata L.), M.Sc. Thesis,54p. Department of Vegetable Science, Dr. Yashwant Singh Parmar University of Horticulture and Forestry, Nauni, Solan (H.P), India.

Burton GW and De Vane EH. 1953. Estimating heritability in tall fescue (Festuca arundinacea) from replicated clonal material. Agronomy Journal 45: 478-481.

Johnson HW, Robinson HF and Comstock
RE. 1955. Estimates of genetic and environmental variability in soybean. Agronomy Journal 47: 314-318.

Kaur M, Chadha S, Kumar N, Sehgal N and Kanwar S. 2018. Characters association and path analysis among CMS and SI based cabbage hybrids under mid hill conditions of Himachal Pradesh, India. International Journal of Current Microbiology and Applied Sciences 7(1): 424-430.

Kibar B, Karaagac O and Kar H. 2014. Correlation and path coefficient analysis of yield components in cabbage (Brassica oleracea var. capitata L.). Acta

ScientiarumPolonorumHortorumCultus 13: 87-97.

Kumar C, Raturi HC andUniyal SP. 2013. Performance of cabbage hybrids under rainfed mid hills conditions of Uttrakhand. Asian Journal of Horticulture8(1): 110-113.

Meena ML, Ram RB andRubee L. 2009. Genetic variability and correlation studies for some quantitative traits in cabbage (Brassica oleracea var. capitata L.) under Lucknow conditions. Progressive Horticulture 41: 89-93.

Panse VG and Sukhatme PV. 1984. Statistical Methods for Agricultural Workers. ICAR, New Delhi.p 381.

Richardson KV. 2013. Evaluation of three cabbage (Brassica oleraceaevar. capitataL.) varieties grown for the fresh market. GRAC Crops research report no. 15. Department of Agriculture, Nassau, Bahamas.

Sharma D. 2001. Horticultural evaluation and variability studies in some cabbage genotypes. M.Sc. thesis, Dr YS Parmar University of Horticulture \& Forestry, Nauni-Solan. (H.P)

Sharma KC. 2010. Genetic variability, characters association and path analysis in exotic lines of cabbage under mid 
hill, sub-humid conditions of Himachal Pradesh. Journal of Hill Agriculture 1: 146-150.

Singh B, Mishra AK, Sanwal SK, Singh PK and Rai M. 2013. Genetic variability and character association analysis in cabbage hybrids. Indian Journal of Horticulture70: 296-299.

Singh BK, Sharma SR and Singh B. 2009. Heterosis for mineral elements in single cross-hybrids of cabbage (Brassica oleracea var. capitata L.). Scientia Horticulturae 122: 32-36.

Singh BK, Sharma SR, Kalia P and Singh B. 2011. Genetic variability for antioxidants and horticultural traits in cabbage. Indian Journal of Horticulture 68(1): 51-55.

Singh J, Upadhyay AK, Bahadur A, Singh B, Singh KP and Mathura R. 2006.
Antioxidant phytochemicals in cabbage (Brassica oleracea var. capitata L.). Scientia Horticulturae 108: 233-237.

Soni S, Kumar S and Maji S. 2013. Correlation and path coefficient analysis studies for the yield and its traits in cabbage (Brassica oleracea var. capitata L.). Annals of Horticulture 6: 331-336.

Thakur $\mathrm{H}$ and Vidyasagar. 2016. Estimates of genetic variability, heritability and genetic advances for yield and horticultural traits in cabbage (Brassica oleracea var. capitataL.). Journal of Environment and Bio-Sciences 30: 155157.

Thakur MC and Thakur AK. 2002a. Genetic variability studies in cabbage. Horticultural Journal 15: 71-76.

\section{How to cite this article:}

Shaina Sharma, Sanjay Chadha, Nitish Sharma and Paras Singh. 2019. Genetic Evaluation of CMS Lines and their Maintainers for Yield and Horticultural Traits in Cabbage (Brassica oleracea var.capitata L.). Int.J.Curr.Microbiol.App.Sci. 8(08): 2398-2408. doi: https://doi.org/10.20546/ijcmas.2019.808.279 